\title{
KUR'AN DIŞI VAHYİN İMKÂN VE VUKUÛNA FARKLI BİR BAKIŞ
}

\author{
A Different View to the Possibility and the Occurrence of Non-Qur'anic Revelation
}

Dr. Öğr. Üyesi Hasan MAÇiN

Adıyaman Üniversitesi, İslami İlimler Fakültesi, İslam Hukuku ABD, Adıyaman, Türkiye, gergeri@ gmail.com

\begin{tabular}{|c|c|}
\hline & Arașttrma Makalesi/ \\
\hline & Öz \\
\hline Makale Bilgisi & $\begin{array}{l}\text { Kur'an dışında vahiy olup olmadığı Hz. Peygamber'in vefatı sonrasından günümüze dek süren bir } \\
\text { tartıșmadır. İlgili literatür incelendiğinde bu konuda üç temel yaklaşımın olduğu görülmektedir. Bu }\end{array}$ \\
\hline $\begin{array}{l}\text { Geliş/Received: } \\
27.06 .2021\end{array}$ & $\begin{array}{l}\text { yaklaşımlar; Kur'an ile birlikte Sünnet'in de vahiy olduğunu söyleyen görüss, Kur'an dışında vahiy kabul } \\
\text { etmeyen görüş ve Sünnet'i bütünüyle vahiy kabul etmemekle birlikte Kur'an dışında da vahyin varlığını }\end{array}$ \\
\hline $\begin{array}{l}\text { Kabul/Accepted: } \\
01.08 .2021\end{array}$ & $\begin{array}{l}\text { kabul eden görüş olarak sıralanabilir. Söz konusu yaklaşım sahipleri görüşlerini bir takım aklî ve naklî } \\
\text { delillere dayandırmışlardır. Bu çalışmada üçüncü yaklaşımın kabulünden hareketle, genelde } \\
\text { peygamberlerin özelde son peygamber Hz. Muhammed'in şahit olduğu bazı olağanüstü hâdiselerin vahiy } \\
\text { olarak kabul edilip edilemeyeceği, vahiy kabul edilmesi durumunda bunun Kur'an dışında vahyin }\end{array}$ \\
\hline $\begin{array}{l}\text { Sayfa/ Page: } \\
133-148\end{array}$ & $\begin{array}{l}\text { varlığına delil olup olamayacağı sorgulanmaktadır. Bu tartışmaya sağlıklı bir cevap verilebilmesi için } \\
\text { öncelikle vahyin ne olduğunun, Kur'an ekseninde ortaya konulması gerekmektedir. Bu çalışmada, vahiy } \\
\text { kavramı Kur'an bağlamında tanıtıldıktan sonra Kur'an'ın yer verdiği bazı peygamberlerle ilgili } \\
\text { tecrübelerin ve bu tecrübeler ile ilgili peygamberlerin aktarımlarının vahiy kapsamında görülüp } \\
\text { görülemeyeceği ile ilgili değerlendirmelere yer verilmektedir. }\end{array}$ \\
\hline
\end{tabular}

Anahtar Kelimeler: Kur'an, Vahiy, Metlüv, Gayr-i Metlüv, Delil.

\begin{abstract}
Whether there is revelation other than the Qur'an or not, is a controversial issue which has been going on since the death of the Prophet (pbuh). When the relevant literature is examined, it can be expressed that there are three basic approaches on this issue. These approaches can be listed as follows; the opinion stating the Sunnah as revelation alongside with the Qur'an, the opinion which refuses any revelation other than the Qur'an and the opinion that accepts the existence of revelation other than the Qur'an, although it does not accept the whole Sunnah as revelation. The owners of the aforementioned approach based their opinions on some logical and traditional evidences. Based on the acceptance of the third approach in this study, it is questioned whether some extraordinary events witnessed by the prophets in general and the last prophet in particular can be accepted as revelation or not, and whether this can be evidence of revelation other than the Qur'an or not. In order to give a sound answer to this discussion, first of all, it is necessary to put forward, within the context of the Qur'an, what the revelation is. In this study, primarily the concept of revelation is discussed within the context of the Qur'an, and afterwards, our evaluations about whether the experiences about some prophets included in the Qur'an and the transmission of the prophets related to these experiences can be considered as revelation or not is put forward.
\end{abstract}

Keywords: Qur'an, Revelation, Recited, Non Recited, Evidence.

Attf/Citation: MAÇİN, H. (2021). Kur'an Dışı Vahyin İmkân ve Vukuûna Farklı Bir Bakış. MECMUA - Uluslararası Sosyal Bilimler Dergisi ISSN: 2587-1811 Y11: 6, Say1: 12, Sayfa: 133-148.

Sorumlu Yazar/Corresponding Author: Dr. Öğr. Üyesi Hasan MAÇĩN

Çatışma Beyanı/Conflict Statement: Makalenin yazar/yazarları bu çalışma ile ilgili taraf olabilecek herhangi bir kişi ya da finansal ilişkileri bulunmadığını dolayısıyla herhangi bir çıkar çatışmasının olmadığını beyan eder/ederler. 


\section{Giriş}

Allah Teâlâ, insanı yarattıktan sonra onu başıboş bırakmamış, ${ }^{1}$ seçtiği elçiler vasıtasıyla ona rehberlik te etmiştir. İlk insanın aynı zamanda peygamber olduğ $\mathrm{u}^{2}$ ve her kavme bir peygamber gönderildiği ${ }^{3}$ nazariitibara alınırsa bu rehberliğin insanlığa yaratılışından itibaren sürekli bir şekilde yapıldığ söylenebilir.

Allah Teâlâ'nın insanlığa rehber olarak göndermiş olduğu peygamberlerle iletişimi literatürde vahiy kavramı ile ifade edilir. ${ }^{4} \mathrm{Bu}$ anlamda her peygamber Allah'tan vahiy almıştır. ${ }^{5}$ Zira nübüvvet doğrudan doğruya vahye dayanır. ${ }^{6}$ Kur'ân-1 Kerîm, Allah'ın peygamberlerle olan iletişiminin farklı şekillerde olabileceğini haber vermektedir. ${ }^{7}$ Peygamberlere verilen kutsal metinlerden oluşan kitap ve sahifelerin vahiy olduğu hususunda herhangi bir tartışma söz konusu değildir. Tartışma, bu kutsal metinler dışında Allah'ın peygamberlerle iletişim kurup kurmadığı, şayet kurmuşsa bu iletişimin nasıl değerlendirilmesi gerektiği ile ilgilidir. Son peygamber özelinde ifade edilecek olursa, Kur'an'ın bir bütün olarak vahiy olduğu hususunda bütün âlimler ittifak halindedir. İhtilaf, Kur'an dışında da Allah'ın Hz. Peygamber'le bir iletişiminin olup olmadığı, şayet bu anlamda bir iletişimi olmuşsa bunun vahiy olarak değerlendirilip değerlendirilemeyeceği hususundadır. ${ }^{8}$ İlgili tartışmalara bakıldığında bu konuda üç temel yaklaşımın olduğu görülmektedir. ${ }^{9}$ Bu yaklaşımlardan biri $\mathrm{Hz}$. Peygamber'in Kur'an dışında da Allah'la iletişiminin bulunduğu ve bütün sözlerinin vahiy olduğu şeklindedir. Başta Zahiriler olmak üzere klasik dönemde birçok âlim Sünnet'i bir istisna yapmadan vahiy olarak değerlendirmiştir. ${ }^{10} \mathrm{Bu}$ görüşe zıt denilebilecek diğer bir yaklaşımın savunucuları ise Allah'ın Hz. Peygamber ile olan iletişiminin Kur'an'dan ibaret olduğunu, dolayısıyla da Kur'an dışında vahiy bulunmadığını öne sürmektedirler. Tarihte yaşanmış bazı tartışmalardan yola çıkarak bu yaklaşımın savunucularını sahabe dönemine kadar geriye götüren araştırmacılar olsa da ${ }^{11}$ bu yaklaşımın bir ekol olarak tarih sahnesine çıkmasının XIX. yüzyılın ikinci yarısından sonra Kur’âniyyûn ile başladığı söylenebilir. ${ }^{12}$ Bu konuda orta yol olarak kabul edilecek diğer yaklaşım ise

1 el-Bakara 2/30-32.

2 el-Bakara 2/37; Âl-i İmrân 3/33.

3 en-Nisâ 4/164; er-Ra'd 13/7; Yunus 10/47; en-Nahl 16/36, 63; Ğâfir 40/78.

${ }^{4}$ Süyûtî, el-ìtkān fì 'ulûmi'l-Kur'ân, I, 160; Tehânevî, Keşşâf, II, 1776; Fazlurrahman, İslâm, s. 42; Ebû Zeyd, Ilahi Hitabın Tabiatı, s. 62.

${ }^{5}$ Cürcânî, Kitâbu't-Ta'rifât, s. 239.

${ }^{6}$ Gölcük ve Toprak, Kelam, s. 321, 341.

7 eş-Şûra 42/51.

${ }^{8}$ Kırbaşoğlu, İslâm Düşüncesinde Sünnet, s. 253-280; Erul, “Kur’an D1ş1 İletişim (Vahy-i Gayri Metluv)”, s. 250, 253.

9 Erul, 'Hz. Peygamber'e Kur'an Dışında Vahiy Geldiğini İfade Eden Rivayetlerin Tahlil ve Tenkidi”, s. 55; Genç, "Sünnet-Vahiy İlişkisis", s. 60.

${ }^{10}$ İbn Hazm, el-İhkâm fì Usûli'l-Ahkâm, I, 96-98, II, 88, III, 91; Beyhakî, el-Esmâ ve's-Slfât, I, 496, 499; Dârimî, es-Sünen, "Mukaddime", 49; Bağdâdî, el-Fakîh ve'l-Mutefakkih, I, 266-67; Gazzâlî, el-Müstasfâ, s. 103; Karaman vd., Kur'an Yolu, V, 158; Şimşek, Hayat Kaynă̆ Kur'an Tefsiri, V, 80.

${ }^{11}$ Hatiboğlu, Hz. Peygamber ve Kur'an Dışı Vahiy, s. 63.

${ }^{12}$ Birışık, "Kur'âniyyûn”, s. 428; Erdoğan, "Teşri Açısından Hadis ve Sünnet”, s. 340-341; Genç, "Sünnet-Vahiy İlişkisi”, s. 71-74; Akcaoğlu, “Hz. Peygamber'in Kur’an Vahyi Dışında Bilgilendirilmesi”, s. 123-130. Ülkemiz Hadis hocalarından Mehmed Said Hatipoğlu, Hz. Peygamber ve Kur'an Dışı Vahiy adlı eserinde Kur'an dışında vahiy olmadığını savunmaktadır. Yazar kitabının tamamında bu konuyu işlemekle birlikte eserinin 63. sayfasında İbn Abbas'ın “Kur'an'dan başka vahiy yoktur” beyanını esas alarak “...biz, Kur'ân-1 Kerîm dışında vahiy aramanın geçersizliğine inanıyor, ...” demek sûretiyle açık bir şekilde Kur'an dışında vahiy olmadığını belirtmektedir. Müellif, aynı eserin 33. sayfasında da Hz. Peygamber'in, “Kur'an'î vahiy olmadan" muhiti haricindeki hâdiseler şöyle dursun, kendi çevresinde fakat gıyabında cereyan eden şeyleri, söylenen sözleri, zihinlerden geçenleri bilemeyeceğini söyleyerek Allah'ın Hz. Peygamberle iletişimini Kur'an vahyinden ibaret saymış olmaktadır. Bkz. Hatiboğlu, Hz. Peygamber ve Kur'an Dışı Vahiy, 33, 63. Yazar Mustafa İslamoğlu da "ilham, işaret, îmâ, ilka, ihsas" kavramlarını vahyin anlam alanında görmesine ve terim olarak vahyi "İlahi mânaların vasıtalı veya vasıtasız bir şekilde peygamberin kalbine ilka edilmesi” şeklinde 
Kur'an dışında vahyin varlığını kabul etmekle birlikte Hz. Peygamber'in bütün söz, fiil ve takrirlerinin vahiy olmadığı şeklindedir. Klasik dönem ve çağdaş birçok ilim adamı bu görüşü savunmaktadır. ${ }^{13}$ Elbette ki her yaklaşımın müdafileri kendi düşüncelerine uygun birtakım aklî ve naklî argümanlar ortaya koymuşlardır. Bu anlamda bir yandan son peygamber Hz. Muhammed'e Kur'an dışında da vahiy geldiği ile ilgili birçok delil ortaya konulmuş, diğer yandan söz konusu delillere, aykırı görüşte olanlarca karşı deliller getirilmiştir. Taraflar bu anlamda bazı Kur'an ayetlerini de karşılıklı olarak delil getirmişlerdir. ${ }^{14} \mathrm{Bu}$ konudaki tartışmaları ilgili eserlere havale ederek bu çalışmada, Kur'an dışı vahye delil olması açısından genelde peygamberlerin, özelde ise son Peygamber Hz. Muhammed'in yaşadığı bazı olağanüstü tecrübelerin Allah ile peygamberler arasında bir iletişim olarak değerlendirilip değerlendirilemeyeceği, bunun bir iletişim olması durumunda peygamberlerin yaşadıkları bu tecrübelerle ilgili aktarımlarının vahiy olarak kabul edilip edilemeyeceği irdelenecektir. Diğer bir ifade ile bu çalışmada genelde peygamberlerin özelde son peygamber Hz. Muhammed'in zaman zaman yaşadıkları ilâhî tecrübeler esnasındaki bilgilenmelerinden yola çıkarak Kur'an dışı vahyin varlı̆̆ının imkânı temellendirilmeye çalışılacaktır.

Kur'an dışı vahyin varlığının imkânına dair böyle bir yöntemin seçilmesi, ilgili tecrübelere, ittifakla vahiy kabul edilen ve sübutu hakkında herhangi bir tartışma bulunmayan Kur'an'ın bizzat değinmiş olmasındandır. Kur'an'ın yer verdiği bu tecrübelerin, Allah ile peygamberler arasında bir iletişim aracı olduğunun makul gerekçelerle ortaya konulması durumunda, söz konusu tecrübelerin bir tür vahiy olarak kabul edilmesi zarureti ortaya çıkar ki, bize göre bu çalışmayı özgün kılan taraf da budur. Böyle bir istidlâlin Kur'an dışı vahyin imkânına referans kabul edilip edilmemesi, vahiy ile neyin kastedildiği ile yakından alakalıdır. Bu anlamda kelimenin Kur'an'da hangi anlamlarda kullanıldığı büyük önem arz etmektedir. Bunun için öncelikle vahiy kavramı Kur'an ekseninde ele alınacak, sonrasında ise Kur'ân-1 Kerîm'in yer verdiği ve bazı peygamberlerin yaşamış oldukları olağanüstü ilâhî tecrübelerinin vahiy ile ilişkisine yer verilecektir.

\section{Vahiy Kavramı}

Vahiy kelimesi sözlükte; îmâ, ${ }^{15}$ işâret, taş üzerindeki yazı, ${ }^{16}$ mektup, kitap, mesaj, ilham, gizli söz, gizli bildiri, ${ }^{17}$ içgüdü, emir ve ateş gibi anlamlara gelir. ${ }^{18}$ Bununla birlikte kelimenin etimolojisinde baskın olarak "bildirim" anlamı olduğu görülmektedir. Zira bu anlamlardan her biri, bir bildirim şeklini ifade etmektedir. ${ }^{19}$ Vahiy kelimesi çeşitli türevleri ile Kur'an'da 70 âyette 78 kez geçmektedir. ${ }^{20}$ Kelimenin Kur'ân-1 Kerîm'deki kullanımına bakıldığında, fiil olarak kullanımında failinin Allah, ${ }^{21}$ insan $^{22}$ ve şeytanlar ${ }^{23}$ olduğu görülür. İlgili âyetlerde fail olarak Allah'ın,

tanımlamasına rağmen, sonraki konuşmalarında Kur'an dışı bir vahyin olmadığını açıkça ifade etmektedir. Bkz. İslamoğlu, Hayat Kitabı Kur'an, s. 1055; Dini Cevaplar, Kur'an dışı vahiy var mıdır?, https://www.youtube.com/watch?v=UufV7-U5MSc (erişim tarihi: 07.05.2021).

${ }^{13}$ Cessâs, el-Fusûl fi'l-Usûl, III, 239-42; Debbûsî, Takvîmu'l-Edille, s. 249; İbnu'l-Ferrâ, el-Udde fi Usûli'l-Flkh, V, 1578-87; Serahsî, Usûlu's-Serahsî, II, 91; Gazzâlî, el-Menhûl, s. 577; Gazzâlî, el-Müstasfâ, s. 346-347; Fahreddin er-Râzî, el-Mahsûl, VI, 7; Yazır, Hak Dini, VII, 261; Karaman vd., Kur'an Yolu, V, 158-59.

${ }^{14}$ Erul, "Kur'an Dışı İletişim (Vahy-i Gayri Metluv)", s. 254-256.

${ }^{15}$ Şeybânî, el-Cîm, III, 314.

16 İbn Düreyd, Cemheretu'l-luğa, I, 231.

${ }^{17}$ İbn Kuteybe, Te'vîlu Müsskili'l-Kur'ân, s. 267; Fîrûzâbâdî, el-Kâmûs, s. 1342.

${ }^{18}$ İbn Manzûr, Lisânu'l-Arab, XV, 379-382; Zebîdî, Tâcü'l- 'arûs, XL, 169-172; Salih, Kur'ân İlimleri, s. 19-21; Demirci, Tefsir Terimleri Sözlüğ̈̈, s. 325.

${ }^{19}$ Ebû Zeyd, Illahi Hitabın Tabiatı, s. 62; Cündioğlu, Sözün Özü, s. 62.

${ }^{20}$ Abdulbâkî, el-Mu'cem, s. 914-915.

${ }^{21}$ Örnek kullanımlar için bkz. Âl-i İmrân 3/44; en-Nisâ 4/163; el-Mâide 5/111; el-Ârâf 7/117, 160; el-Enfâl 8/12; Yunus 10/2, 87; Yusuf 12/15; Tâhâ 20/38; Fussilet 41/12;

${ }^{22}$ Meryem 19/11.

${ }^{23}$ el-En'âm 6/112, 121. 
peygamberlerin yanı sıra ${ }^{24} \mathrm{~Hz}$. Musa'nın annesine, ${ }^{25} \mathrm{~Hz}$. İsâ'nın havarilerine, ${ }^{26}$ meleklere, ${ }^{27}$ yere,${ }^{28}$ göklere $^{29}$ ve arıya $^{30}$ vahyettiği belirtilmektedir. İnsan ve şeytanların fail olduğu kullanımlarda ise vahiy; işaret, imâ, fisıltı, telkin gibi anlamlarda kullanılmaktadır. ${ }^{31}$ Buna göre vahiy kavramı Kur'ân-1 Kerîm'de sözlük anlamı itibariyle Allah ile peygamberler arasında olan bir iletişim türü olmanın yanı sıra, Allah'ın başka varlıklarla ve diğer varlıkların kendi aralarındaki bir tür iletişimi anlamında da kullanılmaktadır. Ancak dinî anlamda vahiyle kastedilen Allah'ın peygamberler ile olan iletişimidir. ${ }^{32}$ Terim olarak vahiy, Allah'ın peygamberlerine hususi bir şekilde ilettiği bildiriler ya da kısaca Allah'ın kelâmını peygamberlerine hususi şekillerde iletmesi olarak tanımlanmaktadır. ${ }^{33}$ Allah'ın peygamberlerle olan bu iletişimi, doğrudan olabileceği gibi melek vasıtasıyla da olabilir. ${ }^{34}$ Buna göre vahiy kelimesi sözlük anlamda da terim anlamda da Kur'an'da kullanılmaktadır. ${ }^{35}$

Vahiy ile alakalı olarak özellikle üzerinde durulması gereken âyet, hiç şüphesiz ki Allah'ın bir beşerle iletişiminin ele alındığı Şûra sûresi 51. âyetidir. Tefsir kaynaklarının aktardığına göre Hz. Peygamber Medine'ye hicret edip Yahudileri İslâm'a davet ettiğinde, Yahudiler kendisinden Mûsâ'nın Allah'la konuşup O’na baktığı gibi Allah'la konuşup O’na bakmasını istediler. Bunun üzerine “Allah bir insanla ancak vahiy yoluyla yahut perde arkasından konuşur. Yahut bir elçi gönderip, izniyle ona dilediğini vahyeder. Şüphesiz O yücedir, hüküm ve hikmet sahibidir." ${ }^{36}$ âyeti nazil oldu. ${ }^{37}$ Âyette Allah'ın insanlarla üç farklı şekilde iletişim kurduğu belirtilmektedir. ${ }^{38}$ Bunlardan birincisi, vahiy yoluyla olmaktadır. Müfessirler buradaki vahiy kavramının sözlük anlamına bağlı olarak, ilham, rüya ve emre amâde kılmak şeklinde üç farklı anlama geldiğini belirtmektedirler. Bu anlamda vahiy; cansız varlıklara, ${ }^{39}$ arıya $^{40}$ ve insanlara ${ }^{41}$ yönelik bir iletişim olabilir. ${ }^{42}$

Âyette Allah'ın bir beşerle iletişimde bulunmasının ikinci şekli, perde ardından konuşmak olarak geçmektedir. Hz. Mûsâ ile konuşmasında olduğu gibi ${ }^{43}$ Allah'ın, kelamını bir cisim üzerinden işittirmesidir. ${ }^{44}$ Kur'ân-1 Kerîm'de bu vahiy türünün, Allah'ın Hz. Mûsâ ile konuşması dışında, bir örneği yer almamaktadır. Hz. Peygamber'in Mi‘rac gecesinde Bakara sûresinin son iki âyetini

${ }^{24}$ en-Nisâ 4/163.

${ }^{25}$ Tâhâ 20/38, 77; eş-Şuarâ 26/52; el-Kasas 28/7.

${ }^{26}$ el-Mâide 5/111.

${ }^{27}$ el-Enfâl 8/12.

${ }^{28}$ ez-Zilzâl 99/5.

${ }^{29}$ Fussilet 41/12.

30 en-Nahl 16/68

${ }^{31}$ el-En'âm 6/112, 121; Meryem 19/11; Râgıb el-İsfahânî, Müfredât, s. 858.

${ }^{32}$ Gölcük ve Toprak, Kelam, 342-43.

33 İbn Manzûr, Lisânu'l-Arab, XV, 380; Tehânevî, Keşşâf, II, 1776; Cerrahoğlu, Tefsir Usûlü, s. 39; Demirci, Tefsir Terimleri Sözlüğü, s. 325; Paçacı, Kur'an'a Giriş, s. 79.

${ }^{34}$ Çalışkan, Tefsir Usûlü, s. 33; Paçacı, Kur'an'a Giriş, s. 79.

${ }^{35}$ Karaman vd., Kur'an Yolu, I, 16.

36 eş-Şûrâ 42/51.

${ }^{37}$ Kurtûbî, el-Câmi', XVI, 53; Şevkânî, Fethu'l-Kadîr, IV, 624.

${ }^{38}$ Mâtürîdî, Te'vîlât, IX, 141.

${ }^{39}$ Fussilet 41/12.

40 en-Nahl 16/68.

${ }^{41}$ el-Kasas 28/7.

42 İbn Kuteybe, Te’vîlu Müşkili'l-Kur'ân, s. 71-75; Mâtürîdî, Te'vîlât, V, 163; İbn Atiyye, el-Muharrer, V, 43; Râgıb el-İsfahânî, Müfredât, s. 859; Şevkânî, Fethu'l-Kadîr, IV, 624; Câbirî, Kur'an'a Giriş, s. 130; Yazır, Hak Dini, VII, 27; Salih, Kur'ân İlimleri, s. 21; Ebû Zeyd, İlahi Hitabın Tabiatı, s. 74; Demirci, Kurân'ın Ana Konularl, s. 146.

43 el-Kasas 28/30.

${ }^{44}$ İbn Kuteybe, Te’vîlu Müşkili'l-Kur'ân, s. 75; Şevkânî, Fethu'l-Kadîr, IV, 624; Câbirî, Fehmü'l-Kur'an, II, 157; Yazır, Hak Dini, VII, 27-29; Ebû Zeyd, İlahi Hitabın Tabiatı, s. 74. 
doğrudan Allah'tan aldığına dair rivayetler olsa da ${ }^{45}$ bu iki âyetin diğer âyetler gibi nazil olduğuna dair öbür rivayetler ${ }^{46}$ Bakara sûresinin Medenî oluşu ve konu ile ilgili gelen başka rivayetlerde bu hususa değinilmemiş olması ${ }^{47}$ birlikte değerlendirildiğinde daha tutarlı görünmektedir.

Âyette bahsedilen üçüncü iletişim türü ise, Allah'ın bir elçi (melek) göndererek dilediğini bildirmesi şeklindedir. Mûsâ (a.s.) dışındaki peygamberlere vahiy çoğunlukla böyle gönderilmiştir. ${ }^{48}$

Vahiy ile ilgili verilen bu bilgiler çerçevesinde, Kur'ân-1 Kerîm'de Allah'ın peygamberlerle olan iletişiminin bir genel anlamda, bir de özel anlamda vahiy olarak isimlendirildiği, Allah'ın peygamberlere göndermiş olduğu kutsal metinlerin "özel anlamda bir vahiy", bunun dişındaki iletişimin ise "genel anlamda vahiy" olarak isimlendirildiği anlaşılmaktadır. ${ }^{49}$

Hadis rivayetlerinde de vahiy kelimesinin Kur'ân-1 Kerîm'deki kullanımına benzer bir şekilde sözlük ve terim anlamında kullanıldığ 1 görülmektedir. İlgili rivayetlerde vahiy kelimesi çoğunlukla Kur'an anlamında kullanılmakla birlikte ilham, sadık rüya vb. iletiler için de kullanılmıştır. ${ }^{50}$

Kur'ân-1 Kerîm'in bir bütün olarak vahiy olduğu hususunda herhangi bir tartışma olmamakla birlikte, vahyin Hz. Peygamber'e ilgili âyette geçen iletişim türünden hangisi ile geldiği hususunda farklı görüşler vardır. Konu ile ilgili âyetler, ${ }^{51}$ Kur'an'ın Hz. Peygamber'e elçi (Cebrail) aracılığıyla bildirildiği yönündedir. ${ }^{52}$ Bazı rivayetler de bu hususu desteklemektedir. ${ }^{53} \mathrm{~Hz}$. Peygamber'in bir defasında eşi Hz. Aişe'ye "Bu Cebrail'dir, sana selam söylüyor." sözünden sonra Hz. Aişe'nin "Benim görmediğimi görüyorsun" 54 sözü, ayrıca bazen sahâbîler tarafından Cebrail'in insan sûretinde görülmesi ${ }^{55}$ vahiy meleğinin Hz. Peygamber'e farklı şekillerde vahiy getirdiğini göstermektedir. ${ }^{56}$

Burada belirtilmesi gereken diğer önemli bir husus ise literatürde vahyin, "metlüv" ve "gayr-i metlüv" şeklinde ikili bir tasnife tabi tutulmuş olmasıdır. Özellikle İmam Şâfî̂’nin, Sünnet'i vahiy ile irtibatlandırmasıyla birlikte, ${ }^{57}$ gelenekte Kur'an "vahy-i metlüv", Sünnet ise "vahy-i gayr-i metlüv" olarak görülmüştür. ${ }^{58}$ Hanefî usulcüler de vahyin bu şekildeki taksimini kabul etmekle birlikte ${ }^{59}$ "celî vahiy"-"hafî̀ vahiy" ${ }^{60}$ ve "zâhir vahiy"-"bâtın vahiy" ${ }^{61}$ şeklinde daha farklı ayrımlara da gitmişlerdir.

Vahiy ile alakalı yapılan bu açıklamalardan sonra, şimdi asıl konumuz olan Kur'an dışı vahye delil olabileceğini düşündüğümüz, Kur'ân-1 Kerîm'de yer verilen bazı peygamberlerin yaşadıkları

\footnotetext{
${ }^{45}$ Ahmed b. Hanbel, el-Müsned, III, 536, IV, 116; Müslim, “İman”, 279; Tirmizî, "Tefsiru'l-Kur’an", 53; Nesâî, "Salât", 1.

${ }^{46}$ Müslim, "İman”, 199; Tirmizî, "Tefsiru'l-Kur’an" 3.

${ }^{47}$ Buhârî, "Salât", 1, "Ehâdîsu'l-Enbiya", 6.

${ }^{48}$ Câbirî, Fehmü'l-Kur'an, II, 157; Yazır, Hak Dini, VII, 28; Ebû Zeyd, Illahi Hitabın Tabiatı, s. 75.

${ }^{49}$ Râgıb el-İsfahânî, Müfredât, s. 858-860.

50 Örnek kullanımlar için bkz. Buhârî, "Nikâh", 107, "Ta'bir", 1, "Vudû", 5, 37, "Tefsîru'l-Kur’an", 335; Müslim, “İmân”, 252, "Mesâcid”, 123, "Cennet”, 64; Ebû Dâvûd, "Edeb”, 48; Tirmizî, "Menâkıb”, 53; Nesâî, "Cenâiz", 115.

${ }^{51}$ el-Bakara 2/97; en-Nahl 16/2, 102; eş-Şuarâ 26/192-194; el-Mü'min 40/15; en-Necm 53/4, 5; et-Tekvîr 81/1921.

${ }^{52}$ Câbirî, Fehmü'l-Kur'an, I, 113; Salih, Kur'ân İlimleri, s. 20-21; Ebû Zeyd, İlahi Hitabın Tabiatı, s. 75.

${ }^{53}$ Mâlik b. Enes, el-Muvatta', 1/202; Buhârî, "Bedu'l-Vahy", 1, "Bedu'l-Halk", 6; Nesâî, “İftitâh", 37.

${ }^{54}$ Buhârî, "Edeb", 111; Müslim, "Fedâil", 91; Dârimî, "İsti' zân", 10.

55 Buhârî, "İmân”, 36; Müslim, "Ma'rifetu'l-İmân", 5.

${ }^{56}$ Salih, Kur'ân İlimleri, s. 24-25; Karaman vd., Kur'an Yolu, I, 15; Özafşar vd., Hadislerle İslam, I, $392-93$.

${ }^{57}$ Şâfîi, el-Umm, V, 136-37, VII, 314.

${ }^{58}$ Mâtürîdî, Te'vîlât, IX, 168; İbn Hazm, el-İhkâm fî Usûli'l-Ahkâm, I, 82; Gazzâlî, el-Müstasfâ, s. 99; Âmidî, elİhkâm, II, 321, III, 150, 152; Bağdâdî, el-Vâdıh fì Usûli’l-Fıkh, III, 392; Kurtûbî, el-Câmi', I, 38; Şevkânî, İşâdül-Fuhûl, I, 96.

${ }^{59}$ Debbûsî, Takvîmu'l-Edille, s. 244; Serahsî, Usûlu's-Serahsî, II, 75.

${ }^{60}$ Debbûsî, Takvîmu'l-Edille, s. 250.

${ }^{61}$ Nesefî, Menâru'l-Envâr, s. 212-213.
} 
tecrübeler ile bu konudaki değerlendirmelerimize geçebiliriz. Çalışma, temelde Kur'an dışı vahye delil olması hasebiyle Hz. Peygamber'in yaşadığı bazı olağanüstü tecrübeler ile alakalı olmasına rağmen konu ile yakın ilgisinden dolayı öncelikle Kur'an'da yer verilen önceki peygamberlerin bu anlamda şahit oldukları hâdiselere de değinmek istiyoruz.

\section{2. Önceki Peygamberlerin Yaşadıkları İlahî Tecrübeler}

Kur'ân-1 Kerîm, peygamberler için beşer vurgusu yapmakla birlikte, onların Allah'tan vahiy aldıklarını ${ }^{62}$ ve bazılarının, normal bir insanın vâkıf olamayacağ ettiklerini de haber vermektedir. Sözü geçen peygamberlerin yaşadıkları bu tecrübelerin içeriği ile ilgili tefsir kaynaklarında birçok rivayete ve te'vile yer verilmiştir. Bu tecrübelerin çalışmamız açısından bizi ilgilendiren tarafi, Allah ile peygamberler arasında bir iletişim vasıtası kabul edilip edilemeyeceği hususu olduğundan, bunların içerikleriyle ilgili detaylar üzerinde durmayı gerekli görmüyoruz. Peygamberlerin yaşamış oldukları bu tecrübelerin Allah ile peygamberler arasında bir nevi iletişim, haliyle de vahyin bir türü olarak kabul edilip edilemeyeceği ile ilgili değerlendirmelerimize, adı geçen peygamberlerin söz konusu tecrübelerini ele aldıktan sonra yer vereceğiz.

Tarihi seyir esas alındığında bu konudaki ilk örneğimiz Hz. İbrahim'dir. Konumuzla alakalı olarak Kur'ân-1 Kerîm, İbrâhim'in (a.s.) iki olayından bahseder. Bu olaylardan ilki Allah'tan ölüleri nasıl dirilttiğini kendisine göstermesini talep etmesi sonrasında yaşanmıştır. İlgili olay Bakara sûresinde şöyle anlatılır:

"İbrahim de bir zaman: "Rabbim, ölüleri nasıl dirilttiğini bana göster!" demişti. (Allah); "İnanmadın mı?" dedi, (Ibrahim): "Hayır (inandim), fakat kalbim tam yatışsın diye (görmek istiyorum) dedi. "O halde kuşlardan dördünü tut, onları kendine çek (kendine alıştır), sonra her dağın başına onlardan bir parça koy. Sonra onları kendine çağır; koşarak sana gelecekler. Bil ki, Allah daima üstün, hüküm ve hikmet sahibidir" dedi. ${ }^{, 63}$ Âyette İbrâhim'in (a.s.), kalbinin mutmain olmas1/yatışmass ${ }^{64}$ için kendisine ölüleri nasıl dirilttiğini göstermesi talebine karşıllk, Allah Teâlâ dört kuş üzerinden bunu kendisine göstereceğini beyan etmektedir. Bu olayın mahiyeti ile ilgili tefsir kitaplarında birçok yorum yapılmıştır. ${ }^{65}$ Olayın mahiyetine dönük tartışmaları ilgili kaynaklara ${ }^{66}$ havale ederek burada bizi ilgilendiren şeyin, kalbinin mutmain olması için ölülerin nasıl diriltildiğinin kendisine gösterilmesi talebinde bulunan İbrâhim'e (a.s.) Allah'ın tatmin edecek bir olayı gözlemleme imkânını bahşetmiş olmasıdır. ${ }^{67} \mathrm{~Hz}$. İbrâhim'in konumuzla alakalı diğer bir olayı En'âm sûresinde geçmektedir. İlgili âyette; "İbrahim'e göklerin ve yerin melekûtunu gösteriyorduk ki, kesin inananlardan olsun."68 denilmek sûretiyle İbrâhim'e (a.s.) inanç hususunda kalben mutmain olması ve kuşku götürmez kesinlikte bir imana ulaşması için göklerin ve yerin melekûtunun kendisine gösterildiği belirtilmektedir. İbrâhim'e (a.s.) gösterilen şeylerin ne olduğu ile ilgili müfessirler farklı şeyler söyleseler de ${ }^{69}$ burada bizim için önemli olan, kendisine gösterilenlerin onun bilgi ve inancı üzerindeki

\footnotetext{
62 el-En'âm 6/91; Yunus 10/2; İbrahim 14/11; el-İsrâ 17/93, 94; el-Kehf 18/110; el-Enbiyâ 21/3; el-Mü'minûn 23/24, 33, 34, 47; eş-Şuarâ 26/154, 186; Yâsîn 36/15; Fussilet 41/6; el-Kamer 54/24; et-Teğâbun 64/6.

${ }^{63}$ el-Bakara $2 / 260$.

${ }^{64}$ İtmi’nan kelimesinin kritiği için bkz. Peker, “İman-Bilgi Münasebeti Bağlamında ‘İtmi’nan’ Kavramı Üzerine Bir Kritik", s. 1073-1080.

${ }^{65}$ Ateş, “Ölülerin Nasıl Diriltildiğinin Kuşlar Üzerinden Hz. İbrahim’e Gösterilmesi”, s. 24-30.

${ }^{66}$ İbn Ebi Hâtim, Tefsîru'l-Kur'âni'l-'azîm, II, 510-14; Taberî, Câmiu'l-beyan, V, 495-511; Fahreddin er-Râzî, Mefâtîhu'l-Gayb, VII, 36-39; Yazır, Hak Dini, II, 180-85.

${ }^{67}$ Yazır, Hak Dini, 2/182-184.

68 el-En‘âm 6/75.

${ }^{69}$ Kurtûbî, el-Câmi', 7/23-25; Yazır, Hak Dini, 3/487.
} 
etkisidir. Zira ilgili âyette Allah'ın gösterdiği şeyler ile İbrâhim'in (a.s.) kesin inanç sahibi olması arasında bir bağ kurulmaktadır. ${ }^{70}$

Kronolojik sıraya göre konu ile ilgili ikinci örneğimiz Hz. Yusuf'a aittir. Yusuf'un (a.s.) Misırda evinde bulunduğu kadının gayr-i meşru talebine karşılık vermeyişi âyette "Rabbinin burhânını görme"sine bağlanmıştır. ${ }^{71}$ İlgili âyetler meâlen şöyledir: "Yusuf'un, evinde kaldı̆̆ kadın, onun nefsinden murad almak istedi ve kapıları kilitleyip: "Haydi gelsene!" dedi (Yusuf): "Allah'a slğınırım dedi, Rabbim(efendim) bana güzel baktı. Zalimler iflah olmazlar!" Andolsun, kadın onu arzu etmişti, eğer Rabbinin burhanın görmeseydi o da onu arzu etmişti. Böylece biz kötülü̆̆̈̈ ve fuhşu ondan çevirmek istedik; çünkü o, ihlasa erdirilmiş kullarımızdandır."72 Âyette Yusuf'u (a.s) gayr-i meşru bir eyleme yeltenmekten vazgeçiren şeyin, "Rabbinin burhanı"nı görmesi olduğu ifade edilmektedir. Konumuz açısından bu görüntünün ne olduğu birinci dereceden önemli değildir. ${ }^{73}$ Burada bizim için asıl önemli olan husus, Yusuf'un (a.s.) görmüş olduğu görüntüden dolayı meşru olmayan bir eylemden sakınmış olmasıdır. Allah Teâlâ bir görüntü ile de olsa peygamberini uyarmış, kötülük ve fuhşu ondan uzaklaştırmıştır. Bu olayda her ne kadar Allah özel anlamda peygamberine vahyetmemişse de bir görüntü ile de olsa kendisini yönlendirdiği görülmektedir.

Konumuzla ilgili diğer bir örnek Hz. Mûsâ'ya aittir. İlgili âyette Mûsâ'nın (a.s.) Allah'ı görme isteği karşısında bunun mümkün olamayacağı kendisine bildirilmiş ve Allah'ın dağa tecelli ettikten sonra dağın darmadağın olması ${ }^{74}$ ile bu husus somutlaştırılmıştır. Allah Teâlâ dağa tecelli ettikten sonra Mûsâ (a.s.) bayılmış ve ayıldığında; "Sen yücesin, sana tevbe ettim, ben inananların ilkiyim!",75 demiştir. Âyette Hz. Mûsâ'ya bazı şeylerin gösterildiği açıkça ifade edilmese de cümlenin bağlamından Hz. Mûsâ'nın, Allah'ın dağa tecelli etmesi sonrasında bazı olağanüstü hâdiselere şahit olduğu ve olanlar karşısında dayanamayıp bayıldığı açıkça anlaşılmaktadır. Mûsâ’nın (a.s.) ayıldıktan sonraki "Sen yücesin, sana tevbe ettim, ben inananların ilkiyim!" ifadesi, yaşadığı tecrübe öncesi Allah'ı görme talebinden vazgeçtiği, artık Allah'ın görülemeyeceği hususunda bir inanca sahip olduğu ve haliyle de itikâdi anlamda, yaşadığı tecrübe öncesinden farklı bir pozisyonda olduğu anlaşılmaktadır. ${ }^{76}$ Öyle anlaş1lıyor ki, Mûsâ (a.s.) şahit olduğu görüntü ile bilgilenmiş ve bu bilgi onun inancı üzerinde etkili olmuştur.

Konu ile ilgili Kur'an'da yer verilen önceki peygamberlere ait örnekleri kısaca bu şekilde belirttikten sonra, şimdi bizim asıl konumuz olan son peygamber Hz. Muhammed'in şahitlik ettiği bazı olağanüstü hâdiseleri ele alabiliriz.

\section{Hz. Peygamber'in Yaşadığı İlahî Tecrübeler}

Yaklaşık yirmi üç yıl süren vahiy sürecinde Hz. Peygamber birçok olağanüstü olaya şahitlik etmiştir. ${ }^{77}$ Özellikle Mi'rac olayında şahit olduğu hâdiseler hadis kitaplarında ayrıntılı bir şekilde yer almaktadır. ${ }^{78}$ Ancak daha önce de belirtildiği gibi bu çalışmada sadece Hz. Peygamber'in Kur'ân-1 Kerim'de yer verilen ilâhî tecrübeleri ele alınacaktır.

\footnotetext{
${ }^{70}$ İtmi'nan ve yakîn kavramları arasındaki anlam ilişkisi ve yakînin dereceleri ile ilgili bir değerlendirme için bkz. Peker, “İman-Bilgi Münasebeti Bağlamında ‘İtmi’nan’ Kavramı Üzerine Bir Kritik”, 1074-1076.

${ }^{71}$ Yusuf 12/24.

${ }^{72}$ Yusuf 12/23, 24.

73 "Rabbinin burhanı" ile ilgili açıklamalar için bkz. Zemahşerî, el-Keşşâf, II, 456-57.

74 el-Ârâf $7 / 143$.

75 el-Ârâf $7 / 143$.

${ }^{76}$ Zemahşerî, el-Keşşâf, II, 155; Kurtûbî, el-Câmi', VII, 278-79; Yazır, Hak Dini, IV, 178-79; Muhammed Esed, Kur'an Mesajı: Meal-Tefsir, s. 299; Şimşek, Hayat Kaynağı Kur'an Tefsiri, II, 326-27.

${ }^{77}$ Buhârî, "Menâkibu'l-Ensâr", 32, 41; Müslim, "Salât", 149-153.

${ }^{78}$ Buhârî, "Menâkibu'l-Ensâr", 42; Müslim, "İmân”, 259.
} 
Kur'an'ın nüzul sırası esas alındığında, Hz. Peygamber'in şahit olduğu olağanüstü hâdiselere işaret eden âyetler ilk olarak Necm sûresinde geçmektedir. İlgili âyetler meâlen şöyledir: "Gözün gördügünü kalp yalanlamadı. Onun gördügünden kuşku mu duyuyorsunuz? Andolsun, onu bir inişinde daha görmüşü̈; Sidretüll-Münteha'nın yanında, ki onun yanında Me'va cenneti vardır. $O$ an sidreyi bürüyen bürümüştü. Göz ne kaydl ne de hedefinden şaştı. Hiç kuşkusuz o, rabbinin en büyük âyetlerinden bir kısmını görmüştü." "79 Âyetlerde geçen zamirin Cebrâil'i mi yoksa Allah'1 mı işaret ettiği, Sidretü'l-Münteha ve Me'vâ cenneti'nin ne ve nerede olduğu ile ilgili tefsir kitaplarında farklı yorumlar yapılmıştır. ${ }^{80}$ Bazı müfessirler "Andolsun, onu bir inişinde daha görmüştü", ve venzeri bir anlatımın olduğu Tekvîr sûresindeki "Andolsun onu apaçık ufukta görmüştür." anlamına gelen (hu/o) zamirinin Allah'1 işaret ettiğini ileri sürerken çoğunluğu oluşturan müfessirler ise bu zamirin Cebrâil'i işaret ettiğini ifade etmişlerdir. İlgili zamirin Cebrâil'i işaret ettiğini söyleyen müfessirler, burada Hz. Peygamber'in Cebrail'i asıl sûretinde gördüğünü belirtmişlerdir. ${ }^{83} \mathrm{~Hz}$. Peygamber'in yaşadığı benzer bir tecrübeye yine Necm sûresinde şöyle değinilmektedir: "And olsun ki, Rabbinin en büyük âyetlerinden bir kısmını gördü." "\$4 Âyette Hz. Peygamber’in gördükleri ile ilgili olarak hadis ve tefsir kitaplarında birçok rivayet ve yoruma yer verilmiştir. ${ }^{85}$

İlgili âyetlerde işaret edilenlerin kimler ve/ya neler olduğu tefsir ilmi ve dolayısıyla da diğer İslami ilimler açısından önemli olmakla birlikte biz burada konu ile ilgili ayrıntıları ilgili kaynaklara havale ederek meselenin bizi ilgilendiren tarafına dikkat çekmek istiyoruz ki o da âyetlerde ayrıntısına girilmeden işaret edilen Hz. Peygamber'in görerek elde ettiği ve çevresiyle paylaştı̆̆ 1 söz konusu bilgilerin bir insanın beşerî çabasıyla vâkıf olabilecek türden bilgiler olup olmadığıdır. Mesela işaret edilenin Cebrâil olması durumunda Hz. Peygamber'in şahit olduklarına dayanarak aktarmış olduğu "Cebrâil'in altı yüz kanadının olduğu" ${ }^{\prime 6}$ bilgisi normal bir insanın beşerî çabasıyla elde edebileceği kesbî bir bilgi mi yoksa Allah'ın seçmiş olduğu elçisine bir bağışı mıdır? Bu bilginin Allah'ın bir bağışı olması durumunda bunun vahiy kapsamında değerlendirilip değerlendirilemeyeceği asıl dikkat çekmek istenen husustur. Konu ile ilgili değerlendirmelerimizi ileriki sayfalara bırakarak şimdilik şu kadarını söyleyebiliriz: Bize göre ele aldığımız konu bağlamında geçen "Onun gördüğ̈̈nden kuşku mu duyuyorsunuz?" 87 âyeti Hz. Peygamber'in yaşadığ tecrübenin sıradan bir insanın beşerî çabasıyla vâkıf olamayacağı bilgiler olduğuna işaret etmektedir. Aksi takdirde insanların kendisiyle gördükleri hakkında kuşku duymaktan söz etmenin bir anlamı olmazdı. Tefsir kaynaklarında ilgili âyetler hakkında yapılan yorumlarda içerik olarak farklılık arz etse de Hz. Peygamber'in normal bir insanın göremeyeceği birçok hakikati gördüğü hususunda birleşmektedir. ${ }^{88}$

Hz. Peygamber'in yaşamış olduğu benzeri bir tecrübe İsrâ sûresinde, "Bir gece, kendisine bazı âyetlerimizi gösterelim diye kulunu Mescid-i Harâm'dan çevresini mübarek kıldığımız Mescid-i

\footnotetext{
79 en-Necm 53/11-18

${ }^{80}$ Taberî, Câmiu'l-beyan, XXII, 500-504; Zemahşerî, el-Keşşâf, IV, 421; Kurtûbî, el-Câmi', XVII, 92-98.

81 en-Necm 53/13.

82 et-Tekvîr $81 / 23$.

${ }^{83}$ Zemahşerî, el-Keşşâf, IV, 713; Yazır, Hak Dini, VII, 263; Derveze, et-Tefsîru'l-Hadîs, II, 76, 80; Câbirî, Fehmü'l-Kur'an, I, 42, 113-15; Karaman vd., Kur'an Yolu, V, 160-162; Şimşek, Hayat Kaynă̆l Kur'an Tefsiri, V, 397-398.

84 en-Necm 53/18.

${ }^{85}$ Buhârî, "Bedu'l-Halk", 7; Müslim, “Îmân”, 282; Tirmizî, "Tefsîru'l-Kur'an", 53; Taberî, Câmiu'l-beyan, XXII, 521-22; Zemahşerî, el-Keşşâf, IV, 421; Derveze, et-Tefsîru'l-Hadîs, II, 76-77; Karaman vd., Kur'an Yolu, V, 159-65.

${ }^{86}$ Taberî, Câmiu'l-beyan, XXII, 504.

${ }^{87}$ en-Necm 53/12.

${ }^{88}$ Taberî, Câmiu'l-beyan, XXII, 521-22; Zemahşerî, el-Keşşâf, IV, 421; Derveze, et-Tefsîru'l-Hadîs, II, 76-77; Karaman vd., Kur'an Yolu, V, 159-65.
} 
Aksâ'ya götüren Allah eksikliklerden münezzehtir. O, gerçekten işitendir, görendir" ${ }^{\prime 89}$ âyeti ile haber verilmektedir. Kimi müfessirlere göre her iki sûrede de Hz. Peygamber'in yaşamış olduğu olay birdir ve isrâ-mi' rac hâdisesini işaret etmektedir. ${ }^{90} \mathrm{Bu}$ olayın nerede, ne zaman ve nasıl meydana geldiği ile ilgili tefsir kaynaklarında farklı görüşler ileri sürülmüştür. ${ }^{91} \mathrm{Bu}$ olayın bir rüya olduğunu söyleyen müfessirler olsa da çoğunluk bunun uyanıkken mucizevî bir şekilde gerçekleşen bir hâdise olduğu görüşündedir. ${ }^{92}$ Çoğunluğun görüşünü esas aldığımızda olayın konumuzla alakalı olan kısmı, sırlarla dolu yolculukta Hz. Peygamber'e gösterilen "âyât" ile ilgili aktarımlarıdır. Aynı sûrenin "Sana gösterdiğimiz o rüyayı ve Kur'an'da lanetlenen ağacı, ancak insanları sinamak için meydana getirdik." 93 âyetinde geçen "rüya" kelimesi hakkında da farklı yorumlar yapılmıştır. Bunu "uyku halinde görülen rüya" olarak değerlendiren müfessirler olduğu gibi "uyanık halde gözle görülen görüntü" anlamını verenler de olmuştur. Müfessirlerin çoğunluğu aynı şekilde âyette geçen rüya kelimesinin isrâ-mi 'rac olayını işaret ettiğini belirtmektedir. ${ }^{94} \mathrm{Bu}$ durumda âyet, Hz. Peygamber'in yaptığı yolculukta şahit olduğu olayları çevresiyle paylaştığına da işaret etmektedir. Aksi takdirde söz konusu kelimenin insanlar için bir sınama vesilesi olmasının bir anlamı olmazdı.

Bazı müfessirler Necm sûresi ve İsrâ sûresindeki ilgili âyetlerde geçen, Hz. Peygamber'in gördüğü "âyât"ın aynı olayla alakalı olduğunu belirtmişlerdir. Mevzumuz açısından ilgili âyetlerin işaret ettiği olayların aynı olup olmaması çok fazla bir ehemmiyet arz etmemektedir. Önemli olan sözü geçen âyetlerde Hz. Peygamber'in şahit olduğu hâdiselerin normal bir insanın kendi çabasıyla vâkıf olamayacağı olağanüstü hâdiseler olması ve Allah'ın peygamberiyle böyle özel bir şekilde iletişim kurmasidır. $^{95}$

Kur'an dışı vahyin varlığına delil olarak getirdiğimiz Kur'an'ın yer verdiği bu olağanüstü hâdiseleri bu şekilde sunduktan sonra konu ile ilgili değerlendirmelerimize geçebiliriz.

\section{Peygamberlerin Yaşadıkları İlahî Tecrübeler ve Kur'an Dışı Vahiy}

İlgili başlıkta da belirtildiği gibi vahiy, Allah ile peygamberler arasında bir tür iletişimdir. $\mathrm{Bu}$ iletişimin; doğrudan, dolaylı, yazılı, sözlü ve görsel olarak gerçekleşmesi mümkün ve vâkidir. Söz konusu iletişim şekillerinin her birisinin Kur'an'da örnekleri mevcuttur. Çalışmaya konu ettiğimiz söz konusu tecrübeler, Allah'ın peygamberlerle olan görsel iletişimi örnekliğinde Kur'an dış1 vahye delil getirilmiştir. Hz. İbrâhim'in ölülerin nasıl diriltildiği ile ilgili gözlemlediği olay ve "göklerin ve yerin melekûtunun" kendisine gösterilmesi, Hz. Yusuf'un "Rabbinin burhanını" görmesi, Hz. Mûsâ'nın, Allah'ın dağa tecelli etmesi sahnesini gözlemlemesi, Hz. Peygamber'in "Rabbinin en büyük âyetlerinden bir kısmını" ve Cebrail'i asıl sûretinde görmesi, söz konusu iletişim şeklinin örnekleri olarak gösterilebilir. Zira mezkûr her bir olayla Allah Teâlâ peygamberlerine bazı mesajlar vermektedir. Peygamberler de aldıkları bu mesajlar ile bilgilenmekte ve bu bilgi onların inanç ve eylemleri üzerinde etkili olmaktadır. Dahası yaşadıkları bu tecrübe onlarla Allah arasında bir sır olarak kalmamakta, zaman zaman bu gözlemlerini ümmetleri ile paylaşmaktadırlar. Hz. İbrâhim'in, ölülerin nasıl diriltildiği ile ilgili gözlemlediği olayla kalbinin yatışması, "göklerin ve yerin melekûtunun" kendisine gösterilmesi ile kesin inanç sahibi olmasi; Hz. Yusuf'un "Rabbinin burhanını" görmesiyle

\footnotetext{
${ }^{89}$ el-İsrâ $17 / 1$.

${ }^{90}$ Kurtûbî, el-Câmi', XVII, 92-96; Derveze, et-Tefsîru'l-Hadîs, II, 81-82; Muhammed Esed, Kur'an Mesajl: Meal-Tefsir, s. 1081; Karaman vd., Kur'an Yolu, III, 458; Şimşek, Hayat Kaynă̆ Kur'an Tefsiri, V. 82.

${ }^{91}$ Taberî, Câmiu'l-beyan, XVII, 332-37.

${ }^{92}$ Taberî, XVII, 331-51; Yazır, Hak Dini, V, 304-10; Mevdûdî, Tefhîmu'l-Kur'an, III, 75-77; Şimşek, Hayat Kaynă̆ Kur'an Tefsiri, III, 198.

${ }^{93}$ el-İ̀sâ $17 / 60$.

${ }^{94}$ Buhârî, "Kader”, 10; Taberî, Câmiu'l-beyan, XVII, 480-484; Mâtürîdî, Te’vîlât, VII, 73; Kurtûbî, el-Câmi', X, 282; Mevdûdî, Tefhîmu'l-Kur'an, III, 121.

${ }^{95}$ Yazır, Hak Dini, VII, 273-74; Derveze, et-Tefsîru'l-Hadîs, II, 77-78.
} 
meşru olmayan bir eyleme yeltenmekten vazgeçmesi ve Hz. Mûsâ'nın, dağa tecelli etmesinden sonra Allah'ın görülemeyeceğine inandığını belirtmesi ${ }^{96}$ söz konusu iletişimdeki mesajların etkileri olarak görülebilir. Hz. Peygamber'in asıl sûretinde Cebrail'i ve "Rabbinin en büyük âyetlerinden bir kısminı" gözlemlemesi olaylarına bağlanan bir sonuç âyetlerde yer almamakla birlikte bu olaylarla ilgili aktardıklarından, onun da gözlemlediği bu olağanüstü hâdiselerden etkilendiği anlaşılmaktadır. Aynı şekilde "Bir gece, kendisine bazı âyetlerimizi gösterelim diye kulunu Mescid-i Harâm'dan çevresini mübarek kaldĭ̆ımız Mescid-i Aksầ ya götüren Allah eksikliklerden münezzehtir. $O$, gerçekten işitendir, görendir " ${ }^{\prime 97}$ âyetinde bazı âyetlerin kendisine gösterilmesi için Hz. Peygamberin Mescid-i Aksâ'ya götürüldüğü belirtilmekte, ancak gösterilen bu âyetlerin neler olduğu açıklanmamaktadır. Gösterilen âyetlerin neler olduğu açıklanmasa da nihayetinde bazı âyetlerin kendisine gösterildiği net bir şekilde anlaşılmaktadır. $\mathrm{Bu}$ durumda adı geçen peygamberler ile Hz. Peygamber'in gözlemlerine dayalı bilgilenmeleri ve aktarımları takdir edilir ki beşerî olmaktan çok ilâhî kaynaklı bir bilgilendirmedir. Vahiy kavramının Kur'an'daki anlam alanı esas alındığında söz konusu iletişim ve bu iletişimde iletilen mesajlar bir tür vahiy olarak değerlendirilebilir. Zira nihayetinde söz konusu mesajlar Allah'tan gelmektedir. Allah'ın peygamberlerle doğrudan ya da dolaylı iletişimi Kur'an terminolojisinde ve literatürde vahiy olarak adlandırılmaktadır. ${ }^{98}$

Hz. Peygamber'in yaşadığı tecrübelerle alakalı aktardığı bilgiler de özel anlamda vahiy (vahy-i metlüv) olarak isimlendirilemese de bunların sırf beşerî bir bilgi olarak değerlendirilmesi de takdir edilir ki doğru bir yaklaşım olmaz. Hz. Peygamber, sözlerinin Kur'an'la karışmaması için gerekli uyarıları yapmış, ${ }^{99}$ Allah'tan kendisine gelen vahiy (Kur'an) ile vahiy kaynaklı sözlerini ve tamamen beşerî vasfi gereği olan sözlerini birbirinden ayırt etmiștir. ${ }^{100}$ Sahâbe de Allah'ın kelamı olması hasebiyle Kur'an'a ayrı bir önem vermekle birlikte Hz. Peygamber'in bazı sözlerine de beşerî bir bilgi olmanın ötesinde anlamlar yüklemişlerdir. Mesela Hz. Peygamber'in isrâ-mi'rac olayıyla ilgili aktarımları ile onun dünya işleriyle ilgili sözleri ya da Cebrâil ile ilgili aktarımlarıyla savaş taktikleri hususundaki görüşleri bir tutulmamıştır. Zira söz konusu olaylarla ilgili aktarımları, beşerî tecrübeye dayalı bilgiler olmadığı gibi hayal ürünü şeyler de değildi. Âyette de belirtildiği gibi "gördüklerini kalbi yalanlamamıştı." ${ }^{, 101}$ Dolayısıyla bu konuda onunla tartışmak müminlere yakışmazdı. ${ }^{102}$ Sonraki dönem âlimleri de Kur'an dışı vahyi Kur'an vahyinden ayırt etmek için farklı tabirler kullanmışlardır. ${ }^{103}$ Literatürde vahyin; 'metlüv' ve 'gayr-i metlüv' olarak farklı şekillerde nitelendirilmesi de Hz. Peygamber'in ilgili sözleriyle Kur'an vahyini birbirinden ayırt etme gereğine duyulan ihtiyacın bir neticesi olarak görülebilir. Hz. Peygamber'in söz konusu edilen aktarımlarının böyle ifade edilmesinin yerinde ve Kur'an'daki vahiy kavramına da uygun bir kullanım olduğu söylenebilir. Çünkü bu olaylara dayalı gözlemlerinin ve gözlemlere dayalı aktarımlarının $\mathrm{Hz}$. Peygamber'in beşerî yönünü aşan bir boyutu vardır. İlgili hâdiselere değinilen âyetlerin bağlamında, söz konusu tecrübelerin Allah tarafından peygamberlere yaşatıldığı anlaşılmaktadır. Allah'ın bazı mesajlar vermek için peygamberlere yaşattığı tecrübelere dayalı bilginin ilâhî yönü, onu vahiy kapsamında değerlendirmede yeterli bir sebep olarak görülebilir. Ancak yanlış bir anlamaya meydan vermemek adına bu noktada şunun da ifade edilmesi gerekir ki, Kur'an dışında Hz. Peygamber'in söz konusu ettiğimiz tecrübelerine dayalı aktarımlarını vahiy kabul etmek, bütünüyle Sünnet'in ya da hadis rivayetlerinin vahiy olduğunu söylemek anlamına gelmez. Kur'an dışında vahiy kabul etmek ile

\footnotetext{
${ }^{96}$ Yazır, Hak Dini, IV, 179.

${ }^{97}$ el-İsrâ 17/1.

${ }^{98}$ Râgıb el-İsfahânî, Müfredât, s. 858-860; Cürcânî, Kitâbu't-Ta'rifât, s. 239.

${ }^{99}$ Müslim, "Zühd ve'r-Rekâik", 72; Dârimî, "Mukaddime", 42.

${ }^{100}$ Salih, Kur'ân İlimleri, s. 30-32; Rahman, İslâm, s. 42.

101 en-Necm 53/11.

102 en-Necm 53/12.

103 Önkal, "Vahiy-Sünnet İlişkisi ve Vahy-i Gayr-i Metluv", s. 57-58.
} 
Sünnet'in bütünüyle vahiy olduğunu söylemek farklı şeylerdir. Sünnet'in bütünüyle vahiy olmadığını söylemek de Kur'an dışında vahiy olmadığı anlamına gelmemektedir. Kur'an dışında vahyin varlığını kabul etmek, zorunlu olarak Hz. Peygamber'in bazı söz, fiil ve takrirlerinin vahiy kaynaklı olmasını kabul etmeyi gerekli hale getirir ki, ifade edilmek istenen tam da budur. Hz. Peygamber'in vahiy kaynaklı bu tür sünnetleri için "vahy-i gayr-i metlüv" ifadesi uygun bir tanımlama olsa da Sünnet'in bir bütün olarak böyle görülmesi bazı tartışmaları da beraberinde getirebilir. Vahyin murakabe ve denetiminde oluşmuş ve adeta vahiy tarafindan onaylanmış olmasından dolayı "takrîrî vahiy" ifadesi genel anlamda Sünnet için daha uygun bir tanımlama olabilir. ${ }^{104}$

Kuran dışında vahiy olmadığını iddia etmek, aslında kutsal metinler dışında peygamberlere vahiy gelmediğini iddia etmenin daha özel bir ifadesidir. Bu durumda kendilerine kutsal metinler verilmeyen peygamberlerin peygamberliğinin, kutsal metinler verilen peygamberlerin ise söz konusu metinler öncesi Allah'la olan iletişimlerinin makul bir izahının yapılması gerekir. Nihayetinde vahiy, Allah ile peygamberler arasında bir tür iletişim olduğuna göre ${ }^{105}$ ve Allah, farklı şekillerde insanlarla iletişimde bulunduğunu beyan ettiğine göre, ${ }^{106}$ insanlara rehberlik yapması için seçmiş olduğu peygamberlerle, onlara verilen kutsal metinler dışında da iletişim kurmasının imkân dahilinde olduğu söylenebilir. ${ }^{107}$ Bunun örneklerini Kur'an, geçmiş peygamberler üzerinden bize haber vermektedir. Hz. İbrahim'e verilen sahifeler dışında ${ }^{108}$ meleklerin kendisine misafir olup gelecekle ilgili bazı olayları haber vermesi, ${ }^{109} \mathrm{~Hz}$. Mûsâ'ya Tevrat tabletleri verilmeden önce Allah'ın perde ardından kendisiyle konuşması ${ }^{110} \mathrm{~Hz}$. İsa'nın kendisine İncil verilmeden önce beşikteyken konuşmas ${ }^{111}$ akla gelen başlıca örneklerdir. Hz. İbrâhim'e gelen meleklerin Lût'un (a.s.) kavmini helak edecekleri bilgisini vermeleri ${ }^{112}$ takdir edilir ki meleklerin kendi başlarına aldıkları bir karar değildir. Tevrat levhaları verilmeden önce Allah'ın Mûsâ (a.s.) ile olan konuşmaları vahiy dışında hangi uygun kavramla ifade edilebilir ki? Hz. Peygamber'den önceki peygamberlerle kendilerine verilen kutsal metinler dışında Allah'ın iletişim kurması vâki ise bu durumun son Peygamber için mümkün görülmemesinin makul bir izahının yapılması gerekir. Ayrıca Kur'an dışı vahyin olmadığı iddiası ile, 'metlüv vahiy' anlamında Mushaf dışında kalan vahiy olmadığı kastediliyorsa, bu konuda birkaç şaz görüş dışında zaten bir tartışma bulunmamaktadır. ${ }^{113}$

Vahiy kavramının Kur'an'daki kullanımı ve literatürdeki anlamı esas alındığında genelde Peygamberlerin, özelde son peygamber Hz. Muhammed'in şahit oldukları olağanüstü hâdiseler ile ilgili aktarımlarının bir tür vahiy olduğu söylenebilir. İlgili başlıkta da belirtildiği gibi Kur'an'da vahiy kavramı kutsal metinleri de kapsayan daha geniş bir anlam alanına sahiptir. Hz. Peygamber'in gerek yukarıda ele aldığımız hâdiselerle ilgili, gerekse de Cebrail ile görüşmelerinde vahiy (Kur'an) almanın dışında şahit olduklarıyla alakalı aktarımları takdir edilir ki beşerî bilgilerin ötesinde şeylerdir. Hz.

${ }^{104}$ Sünnetin vahiyle ilişkisi hususunda bir değerlendirme için bkz. Erdoğan, "Teşri Açısından Hadis ve Sünnet", s. 362-63; Sancakl1, "Sünnet Vahiy İlişkisi”, s. 55-65; Maçin, "F1kıh Usûlü Açısından Geleneksel Sünnet Anlayışına Farklı Bir Bakış", s. 300-309.

105 Ebû Zeyd, Ilahi Hitabın Tabiatı, s. 62.

106 eş-Şûra 42/51.

107 Vahiy kavramının Allah'ın peygamberlerle kutsal metinler dışındaki iletişim anlamı için bkz. Râgıb elİsfahânî, Müfredât, s. 859; Cürcânî, Kitâbu't-Ta'rifât, s. 239.

108 en-Necm 53/36-37; el-Â'lâ 87/18-19.

${ }^{109}$ Hûd 11/69-76; el-Hicr 15/51-60; el-Ankebût 29/31-32; ez-Zâriyât 51/24-37.

${ }^{110}$ Hz. Mûsâ'nın adeta hayat hikayesinin anlatıldığı el-A'râf 7/103-155; Tâhâ 20/9-99 ve el-Kasas 28/2-43 âyetlerinde Tevrat levhalarının kendisine Firavn'un zulmünden kurtulduktan sonra verildiği net bir şekilde anlaşılmaktadır.

111 Âl-i İmrân 3/46; el-Mâide 5/110; Meryem 19/30-34.

112 el-Hicr 15/58-60; el-Ankebût 29/31-32.

${ }^{113}$ Mâlik b. Enes, el-Muvatta', I, 305, II, 824; Ahmed b. Hanbel, el-Müsned, XXLV, 472; Taberî, Câmi'u'lBeyân, X, 559-62; Tahâvî, Şerhu müşkili'l-âsâr, V, 274-79. 
Peygamber'in Cebrail ile ilişkisi bir ses kayıt cihazı gibi mekanik bir ilişkiden ibaret değildir. Cebrail ile olan diyaloglarıyla ilgili rivayetler ${ }^{14}$ dikkate alındığında, Hz. Peygamber'in Kur'an dışında da bazı mesajları Cebrail'den aldığı anlaşılmaktadır. Hz. Peygamber'in isrâ ve mi'rac'da şahit olduğu olaylar ${ }^{115}$ ve Cebrail'in asıl sûretindeki yaratılışı ile ilgili aktarımları, ${ }^{116}$ Cebrail'in insan sûretinde gelip ashâbın huzurunda kendisine bazı sorular sormass ${ }^{117}$ ve insanlara görünmeden Kur'an dışında bazı hususlarda kendisini bilgilendirdiği ${ }^{118}$ ile ilgili rivayetler de bu durumu doğrular niteliktedir. Böyle bir bilgilendirmenin kutsal metinlerden vahiy olması açısından farkının ne olduğu sorgulanabilir. Çalışmanın maksadını aşacağından dolayı burada bu konuya girmeyi uygun bulmuyoruz. Ancak şu kadarını söyleyebiliriz ki, Kur'an vahyi ile bu tür bilgiler arasında çok ciddi mahiyet farkı bulunmaktadır. Zira ilki Allah'tan gelmiş mahza vahiyler iken ikincisi peygamberlerin şahit oldukları hâdiselerin aktarımından ibarettir. $\mathrm{Bu}$ anlamda bu tecrübelerin Allah tarafindan yaşatılmış olmasından ötürü ilâhî bir yönü olmakla birlikte, bunlar Hz. Peygamber'in beşer olması bakımından ise beşerî yönü de olan ilâhî ihbarlardır. ${ }^{119}$

\section{Sonuç}

Allah Teâlâ'nın diğer varlıklarla iletişimi, Kur'an'da vahiy kavramı ile ifade edilmektedir. Kur'an'daki vahiy kavramı dikkatle incelendiğinde, Allah'ın peygamberler yanı sıra, Hz. Musa'nın annesine, Hz. İsâ'nın havarilerine, meleklere, yere, göklere ve arıya vahyettiği net bir şekilde görülür.

Allah'ın peygamberlerle iletişimi anlamında vahiy değişik şekillerde olabilmektedir. Allah Teâlâ bir peygamberle doğrudan ya da bir elçi (melek) vasıtasıyla dolaylı olarak iletişim kurabilir. Kur'an'ın, bazı peygamberlerin şahit olduklarını haber verdiği olağanüstü hâdiseler de bize göre bu iletişimin örnekleri olarak görülebilir. Hz. İbrâhim'in, ölüleri nasıl dirilttiğini kendisine göstermesine karşılık, Allah'ın dört kuş örneği üzerinden bunu kendisine öğretmesi ve "göklerin ve yerin melekûtunun" kendisine gösterilmesi, Hz. Yusuf'un "Rabbinin burhanını" görmesi, Hz. Mûsâ'nın, Allah'ın dağa tecelli etmesi sahnesini gözlemlemesi, Hz. Peygamber'in "Rabbinin en büyük âyetlerinden bir kısmını" ve Cebrail'i asıl sûretinde görmesi Kur'an'ın bu anlamda yer verdiği örnekler olarak sunulabilir. Kur'an söz konusu örnekleri haber vermekle birlikte bunların detaylarına girmemektedir. Adı geçen peygamberlerin şahit oldukları olaylar ile ilgili aktarımların ilâhî bir bilgilendirme, dolayısıyla bir tür vahiy olduğu söylenebilir. Bu anlamda Hz. Peygamber'in yaşamış olduğu olağanüstü hâdiseler ile ilgili aktarımları da takdir edilir ki beşerî bir tecrübenin ötesinde, ilâhî bir bilgilendirmenin ürünü olan haberlerdir. Normal bir insanın vâkıf olamayacağı böylesi tecrübeler ile ilgili aktarımlar, ilâhî kaynaklı olması hasebiyle Kur'an'î terminolojiye göre vahiy olarak isimlendirilebilir.

Sonuç olarak şunu ifade edebiliriz ki, Allah Teâlâ'nın peygamberler ile olan iletişimi kutsal metinlerden ibaret olmayıp O'nun, elçileriyle söz konusu metinler dışında da iletişimi olmuştur. Bu anlamda indirdiği Kitap ile birlikte, ilgili âyette belirtilen diğer iletişim şekilleriyle de zaman zaman Hz. Peygamber ile iletişim kurmuştur. Hz. Peygamber'in yaşamış olduğu ilahi tecrübeler de bu iletişim türünden biri kabul edilebilir. Söz konusu iletişimin ilâhî kaynaklı olması, bunun vahiy

\footnotetext{
${ }^{114}$ Buhârî, "İman”, 36, "Salât”, 1, "Mevâkîtu's-Salât", 1, "İstikrâd”, 3, "Bedu'l-Halk", 6, 7, "Ehâdîsu'l-Enbiya", 1; Müslim, "İmân”, 153, 259, 346, "Mesâcid”, 166, "Salâtu'l-Müsâfirîn" 254, "Libâs", 16, 81, "Selâm”, 40, "Birr", 140; Dârimî, "Mukaddime" 4, "Salat", 2, "Menâsik", 14.

115 Buhârî, "Mevâkîtu's-Salât", 1, "Bedu'l-Halk", 6; Müslim, "İmân”, 259.

${ }^{116}$ Buhârî, "Bedu'l-Halk", 7; Müslim, "İmân”, 257, 280.

${ }^{117}$ Buhârî, "İmân", 36; Müslim, "Tahâret",1.

118 Buhârî, "İstikrâd”, 3, "Bedu'l-Halk", 6, "Edeb”, 28; Müslim, “İmân”, 153, "Birr”, 140; Mâlik b. Enes, elMuvatta', 1/334, 2/461.

${ }^{119}$ Hamidullah, Kur'ân-ı Kerîm Tarihi, s. 15-16; Erul, “Kur’an Dişı İletişim (Vahy-i Gayri Metluv)”, s. $278-279$.
} 
kapsamında değerlendirilmesi için yeterli bir sebeptir. Ancak Kur'an vahyinden (vahy-i metlüv) ayırt edilmesi adına, literatürdeki Kur'an dışı vahiy anlamındaki "gayr-i metlüv" ifadesi bu tür vahiy için de uygun bir niteleme olarak görülebilir.

\section{Kaynakça}

Abdulbâkî, Muhammed Fuad. el-Mu'cemu'l-mufehres li elfâzi'l-Kur'ân. Beyrut: Dâru'l-Ma'rife, 1991.

Ahmed b. Hanbel, Ebû Abdillâh Ahmed b. Muhammed b. Hanbel eş-Şeybânî. el-Müsned. Müessesetu'r-Risâle, 2001.

Akcaoğlu, Faik. "Hz. Peygamber'in Kur'an Vahyi Dışında Bilgilendirilmesi”. Doktora Tezi, Marmara Üniversitesi Sosyal Bilimler Enstitüsü, 2010.

Âmidî, Ebu'l-Hasan Seyfuddîn Ali b. Muhammed. el-İhkâm fì Usûli'l-Ahkâm. 4 c. Beyrut: elMektebu'l-İslâmî, ts.

Ateş, Abdurrahman. "Ölülerin Nasıl Diriltildiğinin Kuşlar Üzerinden Hz. İbrahim’e Gösterilmesi”. İn̈nü Üniversitesi Illahiyat Fakültesi Dergisi 7, sy 1 (2016): 9-34.

Bağdâdî, Ebû Bekr Ahmed b. Ali b. Sâbit. el-Fakîh ve'l-Mutefakkih. 2. bs. 2 c. Suudi Arabistan: Dâr-u İbni'l-Cevziyye, ts.

Bağdâdî, Ebû'l-Vefa Ali b. Akîl b. Muhammed. el-Vâdıh fì Usûli'l-Fıkh. 5 c. Beyrut: Muessesetu'rRisâle, 1999.

Beyhakî, Ebû Bekr Ahmed b. el-Huseyn. el-Esmâ ve's-Slfât. 2 c. Cidde: Mektebetü's-Süvâdî, 1993.

Birışık, Abdulhamit. “Kur'âniyyûn”. Türkiye Diyanet Vakfi İslâm Ansiklopedisi, 26:428-29. Ankara: TDV İslâm Araştırmaları Merkezi, 2002.

Buhârî, Ebû Abdillah Muhammed b. İsmail. el-Câmi 'u's-sahîh. 9 c. Dimaşk: Dâru Tavki'n-Necât, 2001.

Câbirî, Muhammed Âbid. Fehmü'l-Kur'an Nüzul Sirasına Göre Tefsir. Çeviren Muhammed Coşkun. 3 c. İstanbul: Mana Yayınları, 2013.

- Medhal ile'l-Kur'âni'l-Kerîm (Kur'an'a Girişs). Çeviren Muhammed Coşkun. 3. bs. İstanbul: Mana Yayınları, 2013.

Cerrahoğlu, İsmail. Tefsir Usûlü. 6. bs. Ankara: Türkiye Diyanet Vakfı Yayınları, 1988.

Cessâs, Ebû Bekr Ahmed b. Alî er-Râzî. el-Fusûl fi'l-Usûl. 2. bs. 4 c. Kuveyt: Vizârutu'l-Evkâf elKuveytiyye, 1994

Cündioğlu, Dücane. Sözün Özü (Kelâmı Illahi’nin Tabiatına Dair). 3. bs. İstanbul: Kaknûs Yayınları, 2005.

Cürcânî, Ali b. Muhammed. Kitâbu't-Ta'rifât. Beyrut: Dâru'l-Kutubi'l-İlmiyye, 1983.

Çalışkan, İsmail. Tefsir Usûlü. Ankara: Ankara Okulu Yayınları, 2017.

Dârimî, Ebû Muhammed Abdullah b. Abdirrahman. es-Sünen. b.y.: Dâru'l-Muğnî, 2000.

Debbûsî, Ebû Zeyd Abdullah b. Ömer. Takvîmu'l-edille fì usûli'l-fikh. b.y.: Dâru'l-Kutubi'l-İlmiyye, 2001.

Demirci, Muhsin. Kurân'ın Ana Konuları. 4. bs. İstanbul: Marmara Üniversitesi İlahiyat Fakültesi 
Vakfi Yayınları, 2008.

. Tefsir Terimleri Sözlüğ̈̈. 7. bs. İstanbul: Marmara Üniversitesi İlahiyat Fakültesi Vakfı Yayınlar1, 2018.

Derveze, Muhammed İzzet. et-Tefsîru'l-Hadîs. 10 c. Kahire: Dâru İhyâi'l-Kutubi'l-Arabiyye, 1983.

Dini Cevaplar. Kur'an dışı vahiy var mıdır? https://www.youtube.com/watch?v=UufV7-U5MSc.

Ebû Dâvûd, Süleyman bin el-Eşas. es-Sünen. 7 c. b.y.: Dâru'r-risâleti'l-âlemiyye, 2009.

Ebû Zeyd, Nasr Hâmid. İlahi Hitabın Tabiatı. Çeviren Mehmet Emin Maşalı. 3. bs. Ankara: Otto Yayınlar, 2013.

Erdoğan, Mehmet. "Teşri Açısından Hadis ve Sünnet”. Kur'an Sünnet İlişkisi Kur'an'da Risâlet ve Sünnet’in Teşrî̀ Değeri, editör Bünyamin Erul, 331-48. İstanbul: Kuramer Yayınları, 2020.

Erul, Bünyamin. “Hz. Peygamber'e Kur'an Dışında Vahiy Geldiğini İfade Eden Rivayetlerin Tahlil ve Tenkidi”. İslâmiyât 1, sy 1 (1998): 55-72.

. "Kur'an D1şı İletişim (Vahy-i Gayri Metluv)". Kur'an Sünnet İlişkisi Kur'an'da Risâlet ve Sünnet'in Teşriî Değeri, editör Bünyamin Erul, 249-84. İstanbul: Kuramer Yayınları, 2020.

Fahreddin er-Râzî, Ebû Abdillah Fahruddin Muhammed b. Ömer b. Hüseyn. el-Mahsûl. b.y.: Müessesetu'r-Risâle, 1997. . Mefâtîhu'l-Gayb (et-Tefsîru'l-Kebîr). Beyrut: Dâru İhyâi't-Turâsi'l-Arabî, 1999.

Fazlurrahman. İslâm. Çeviren Mehmet Aydın ve Mehmet Dağ. 3. bs. İstanbul: Selçuk Yayınları, 1993.

Fîrûzâbâdî, Ebü’t-Tâhir Mecdüddîn Muhammed b. Ya'kūb. El-Kāmûsü’l-Muhît. Beyrut: Müessesetu'r-Risâle, 2005.

Gazzâlî, Ebû Hâmid Muhammed b. Muhammed et-Tûsî. el-Menhûl min Ta'likkâti'l-Usûl. 3. bs. Dimeşk: Dâru'l-Fikr, 1998. - el-Müstasfâ. b.y.: Dâru'l-Kutubi'l-İlmiyye, 1993.

Genç, Mustafa. "Sünnet-Vahiy İlişkisi”. Doktora Tezi, Selçuk Üniversitesi, Sosyal Bilimler Enstitüsü, 2005.

Gölcük, Şerafettin - Toprak, Süleyman. Kelam. 9. bs. Konya: Tekin Kitabevi, 2016.

Hamidullah, Muhammad. Kur'ân-ı Kerîm Tarihi. Çeviren Salih Tuğ. İstanbul: Marmara Üniversitesi İlahiyat Fakültesi Vakfı Yayınları, 1993.

Hatiboğlu, Mehmed Said. Hz. Peygamber ve Kur'an Dışı Vahiy. 2. bs. Ankara: Otto Yayınlar, 2009.

İbn Atiyye, Ebû Muhammed Abdu'l-Hak b. Gâlib. el-Muharreru'l-vecîz fì tefsîri'l-kitâbi'l-azîz. Beyrut: Dâru'l-Kutubi'l-İlmiyye, 2001.

İbn Düreyd, Ebû Bekr Muhammed b. el-Hasen el-Ezdî el-Basrî. Cemheretu'l-luğa. 3 c. Beyrut: Dâru'l-ìlm lil Melâyin, 1987.

İbn Ebi Hâtim, Ebû Muhammed Abdurrahman b. Muhammed b. İdris b. er-Râzî. Tefsîru'l-Kur'âni'l'azîm. 3. bs. Suudi Arabistan: Mektebetü Nizâr Mustafa el-Bâz, 1998.

İbn Hazm, Ebû Muhammed Ali b. Ahmed b. Said. el-İhkâm fì Usûli'l-Ahkâm. 8 c. Beyrut: Dâru'lÂfâki'l-Cedide, ts.

İbn Kuteybe, Ebû Muhammed Abdillah b. Müslim. Te’vîlu Müşkili'l-Kur'ân. Beyrut: Dâru'l-Kutubi'1- 
İlmiyye, ts.

İbn Manzûr, Ebû'l-Fadl Cemâluddin Muhammed b. Mukerrem. Lisânu'l-Arab. 3. bs. 15 c. Beyrut: Dâr-u Sadr, 1993.

İbnu'l-Ferrâ, el-Kâdî Ebû Ya'la Muhammed b. el-Huseyn b. Muhammed b. Halef. el-Udde fi Usûli'lFikh. 2. bs. 5 c. b.y., 1990.

İslamoğlu, Mustafa. Hayat Kitabı Kur'an Gerekçeli Meal-Tefsir. 2. bs. İstanbul: Düşün Yayıncılık, 2008.

Karaman, Hayreddin, Mustafa Çağrıcı, İbrahim Kâfi Dönmez ve Sadrettin Gümüş. Kur'an Yolu Türkçe Meâl ve Tefsir. 3. bs. 5 c. Ankara: Diyanet İşleri Başkanlığı Yayınları, 2007.

Kırbaşoğlu, M. Hayri. İslâm Düşüncesinde Sünnet. Ankara: Ankara Okulu Yayınları, 1997.

Kurtûbî, Abû Abdillâh Muhammed b. Ahmed. el-Câmi’li ahkâmi'l-Kur'ân. Kahire: Dâru'l-Kutubi'lMisriyye, 1964.

Mâlik b. Enes, Ebû Abdillâh b. Mâlik b. Ebî Âmir el-Asbahî. el-Muvatta'. Ebu Zabi: Müessesetu Zâyed b. Sultan, 2004.

Maçin, Hasan. "Fıkıh Usûlü Açısından Geleneksel Sünnet Anlayışına Farklı Bir Bakış". Kavramlar ve Kuramlar -Din Bilimleri-, editör M. Nesim Doru ve Kamuran Gökdağ, 289-317. Mardin: Mardin Artuklu Üniversitesi Yayınları, 2020.

Mâtürîdî, Ebû Mansûr Muhammed b. Muhammed. Tefsiru'l-Mâtürîdî (Te'vîlâtu Ehl-i Sünne). Beyrut: Dâru'l-Kutubi'l-i̇lmiyye, 2005.

Mevdûdî, Ebu'l-Âlâ. Tefhîmu'l-Kur'an. Çeviren Muhammed Han Kayânî. 2. bs. İstanbul: İnsan Yayınları, 1991.

Muhammed Esed. Kur'an Mesajı: Meal-Tefsir. Çeviren Cahit Koytak ve Ahmet Ertürk. 7. bs. Ankara: İşaret Yayınları, 2000.

Müslim, Ebü'l-Hüseyn Müslim b. el-Haccâc. el-Câmi 'u's-sahîh. 5 c. Beyrut: Daru İhyâi’t-Turâsi'lArabî, ts.

Nesâî, Ebû Abdirrahmân Ahmed b. Şuayb. es-Sünen. Halep: Mekteb-u Matbuâti'l-İslâmiyye, 1986.

Nesefî, Ebu'l-Berekât. Menâru'l-Envâr. Çeviren Soner Duman, Osman Güman ve Süleyman Kaya. İstanbul: Beka Yayıncilık, 2018.

Önkal, Ahmet. "Vahiy-Sünnet İlişkisi ve Vahy-i Gayr-i Metluv", 55-69. Ankara, 1997.

Özafşar, Mehmet Emin, İsmail Hakkı Ünal, Yavuz Ünal, Bünyamin Erul, Huriye Martı ve Mahmut Demir, ed. Hadislerle İslam. 7 c. Ankara: Diyanet İşleri Başkanlığı Yayınları, 2014.

Paçacı, Mehmet. Kur'an 'a Giriş. İstanbul: İsam Yayınları, 2013.

Peker, Hasan. “İman-Bilgi Münasebeti Bağlamında ‘İtmi’nan’ Kavramı Üzerine Bir Kritik”, 1071-82. Gümüşhane: Gümüşhane Üniversitesi Yayınları, 2019.

Râgıb el-İsfahânî, Ebü'l-Kāsım Hüseyn b. Muhammed b. el-Mufaddal. Müfredâtü elfâzi'l-Kur'ân. Dimeşk: Dâru'l-Kalem, 1992.

Salih, Subhi. Kur'ân İlimleri. Çeviren M. Sait Şimşek. 3. bs. İstanbul: Hikmetevi Yayınları, 2015.

Sancakl1, Saffet. "Sünnet Vahiy İlişkisi”. Diyanet İlmî Dergi 34, sy 3 (1998): 53-70.

Serahsî, Muhammed b. Ahmed b. Ebi Sehl. Usûlu’s-Serahsî. 2 c. Beyrut: Dâru'l-Ma‘rife, ts. 
Süyûtî, Ebü'l-Fazl Celâlüddîn Abdurrahmân b. Ebî Bekr b. Muhammed el-Hudayrî. el-İtkān fí 'ulûmi'l-Kur'ân. 4 c. el-Hey'etu'l-Misriyye el-âmme lil Kitab, 1974.

Şâfiî, Ebû Abdillâh Muhammed b. İdrîs. el-Umm. 8 c. Beyrut: Dâru'l-Ma'rife, 1990.

Şevkânî, Ebû Abdillâh Muhammed b. Alî b. Muhammed. İş̧âdü'l-fuhûl ilâ tahkîki'l-hak min 'ilmi'lusûl. 3. bs. 2 c. Beyrut: Dâru'l-Kitâbi'l-Arabiyyi, 2003.

Şevkânî, Muhammed b. Ali b. Muhammed. Fethu'l-Kadîr. Dimeşk: Dâr-u İbn Kesir, 1993.

Şeybânî, Ebu Amr İshâk b. Merrâr. el-Cîm. 3 c. Kahire: el-Hey'etu'l-Âmme li Şuûni'l-Metâbi'lEmîriyye, 1974.

Şimşek, M. Sait. Hayat Kaynağı Kur'an Tefsiri. İstanbul: Beyan Yayınları, 2012.

Taberî, Muhammed b. Cerir b. Yezîd. Câmiu'l-beyan fì te'vîli'l-Kur'ân. 24 c. Muessesetu'r-Risâle, 2000 .

Tehânevî, Muhammed A'lâ b. Alî b. Muhammed Hâmid. Keşşâfü ıstılâhâti'l-fünûn ve'l-'ulûm. Beyrut: Mektebetu Lübnan, 1996.

Tahâvî, Ebû Ca'fer Ahmed b. Muhammed b. Selâme. Şerhu müşkili'l-âsâr. 16 c. b.y.: Müessesetu'rRisâle, 1994.

Tirmizî, Ebû İsâ Muhammed b. İsâ. es-Sünen. 2. bs. 5 c. Mısır: Matbaat-u Mustafa el-Bâbî, 1975.

Yazır, Elmalı1ı Muhammed Hamdi. Hak Dini Kur'ân Dili. 9 c. İstanbul: Yenda Yayınevi, 1997.

Zebîdî, Ebü'l-Feyz Muhammed el-Murtazâ b. Muhammed. Tâcü'l- 'arûs min cevâhiri'l-kâmûs. 40 c. Dâru'l-Hidâye, ts.

Zemahşerî, Ebû'l-Kâsım Mahmud b. Amr b. Ahmed. el-Keşşâf. 3. bs. 4 c. Beyrut: Dâru'l-Kitâbi'1Arabiyyi, 1987. 